\title{
THE RELATIONSHIP BETWEEN HEALTH DEVELOPMENT INDEX AND FINANCIAL DEVELOPMENT INDEX: EVIDENCE FROM HIGH INCOME COUNTRIES
}

\section{Sağlık Gelișim Endeksi ile Finansal Gelișme Endeksi Arasındaki İlișki: Yüksek Gelirli Ülkelerden Örnekler}

\section{Ayhan KULOĞLU ${ }^{1}$ \& Eyyup ECEVIT ${ }^{2}$}

Keywords:

Health, Human Capital, Financial Development

JEL Classifications: I1, J24, B26

Anahtar Kelimeler: Sağlık, Beşeri Sermaye, Finansal Gelişme

Jel Kodları: I1, J24, B26

\begin{abstract}
Economic growth is a complex process affected by many factors at different levels which is commonly proxied by health. In this study, the causal between health and financial development is investegated using heteregenuis panel causality test over the period 1991-2014. To this end, Principal component analysis is initially applied to construct indexes for each variable. Results show that health development indexgranger causes financial development index.
\end{abstract}

\section{Özet}

Ekonomik büyüme, sağlık değişkeni tarafından sıkça rastlanan farklı seviyelerde birçok faktörden etkilenen karmaşık bir süreçtir. Bu çalışmada, sağlık ve finansal değişkenler arasındaki nedensellik ilişkisi 1991-2014 yılları boyunca panel nedensellik testi kullanılarak araştırılmıştır. Bu amaçla, temel bileșenler analizi değişkenlerden dizinler elde etmek için başlangıçta uygulanmıştır. Sonuçlar, sağlık gelişme endeksinin finansal gelişme endeksinin granger nedeni olduğunu göstermektedir.

\section{Introduction}

Health status of the community is an important element contributing significantly to the development and feeding of human capital. The health status of the community has a close relationship with the economic developments. However, improvement of health level is also accelerating economic growth through increased productivity.

Researchers analyzed extensively the relationship between economic variables (economic growth rate, price, income... etc.) and health variables (fertility rate, mortality rate, life expectancy at birth... etc.) in the literature with regard to the various time periods and group of countries. Health index has been established on the single variables (life expentancy at birth) in the United Nations Development Programme (UNDP) ${ }^{3}$. Human capital health index (HCHI) was created by the merger of eight variables using Principal Component Analysis (PCA) in our

\footnotetext{
${ }^{1}$ Yrd.Doç.Dr.,Nevşehir Hacı Bektaş Veli Üniversitesi, Meslek Yüksekokulu, Muhasebe ve Vergi Uygulamaları Bölümü, e-mail: akuloglu@nevsehir.edu.tr (Corresponding Author)

${ }^{2}$ Doç.Dr., Erciyes Üniversitesi, İktisadi ve İdari Bilimler Fakültesi, İktisat Teorisi ve İktisat Tarihi ABD, e-mail: eyyupecevit@erciyes.edu.tr

${ }^{3}$ http://hdr.undp.org/en/content/health-index, Date of Access: 18.10.2017
} 
paper. Similarly, eleven financial variables indicating the level of economy are converted to a single variable as financial development index (FDI). In addition that, FDI is diveded into three sub-index (bank index-bi, bound marketing index-bmi and stock marketing index-smi) using the combination of different variables. Unlike previous studies in the literature, the main objective of this study is to test the relationship between human capital health index (HCHI) and financial development index (FDI) over the period 1991-2014 in the ten high income countries by obtaining indexes for both variables using various indicators.

There exists a great number of theoretical and empirical studies between human capital economic growth and financial development in the literature. Among these studies, a large body of these studies examine the nexus between economic growth and, education and health which are the determinants of human capital. In the literature, there is not enough empirical work between the determinants of human capital (education and health) and financial development, while financial growth is defined by the determinants and contributions of human capital to economic growth. Apart from constructing broad-defined indexes for both variables, existing study aims to contribute to the literature in two ways. First, there is not enough empirical study between financial development and health index in the literature. Second, since there is a strong relationship between economic growth, financial development and human capital on developed countries, it is necessary to analyze the relationship between financial development and health change in high-income countries.

The portions of the study are as follows. The second section includes a summary of the literature and theory; the third section covers definition of our variables, econometric method and hypotheses we apply in our work. Regression results and findings are shown in section 4; and finally, section 5 suggests some conclusions and discussions our regression findings.

\section{Theory and Literature Review}

The classical factors of production which play a role in the economic growth process and are defined as labor, capital, natural resources and enterprise, are inadequate in explaining economic developments today. Neoclassical growth model emphasizes the accumulation of physical capital and the importance of labor in the growth process. The only source of total factor productivity is external technological development. In this regard, the model suggests that any policy would not increase the output per worker and growth per capita in the long run. Studies by Arrow (1962), Kaldor and Mirrlees (1962) and Uzawa (1965) have improved argument that technological development will be explained internally as opposed to the Solow model. Romer (1986) also supported the argument of internal technology with increasing returns. After the mid-1980s, new rapid growth models of internal growth emerged. In the theories of internal growth which have been developed with the contributions of Lucas (1988), Barro (1990) and Rebelo (1991), the opinion that economic growth can be increased with health, education and technology policies. Thus, according to theories of internal growth; governments may increase economic growth through education and health as the two main determinants of human development. Internal growth models express that human capital is an important factor in terms of long-term growth. Human capital enables the efficient use of other factors in the production process, the invention of new technologies and their rational use. According to the theory of human capital, improving one's knowledge and skill increases the 
productivity in economic activities. For the development of human capital, there is a need educated and healthy society.

Generally, healthy societies are confronted as communities that are productive, productive and prosperous. Health is also an essential element of labor productivity by increasing mental, physical and emotional learning capacity in schools. A healthy society is the most important input for economic growth. Mushkin (1962) and Grossman (1999) describe health as important elements of human capital.

Soukiazis and Cravo (2008) is expressed that the convergence between the countries is dependent on human capital, physical capital, structural factors and population. As a result of this convergence, the following figure 1 emerges among the countries. This relationship is more prominent in less developed countries than in developed countries.

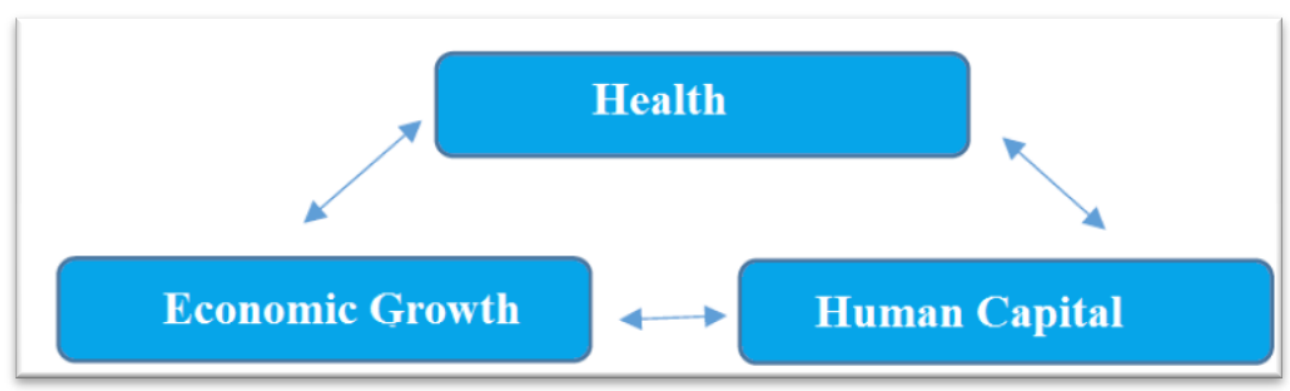

Figure 1: Health, Human Capital and Economic Growth Relation

Source: Soukiazis, E., Cravo, T. (2008), Human Capital and the Convergence Process among Countries, Review of Development Economics, 12(1): 124-142.

There have been many studies to examine the relationship between health variables and dynamics of the economy in the literature. The first of these studies is Grossmann (1972)'s work. According to this study, health care expressed as the fixed capital stock affects economic growth positively. Health spending as a kind of investment promotes economic growth. From the other direction, Newhouse (1977) stated that GDP has a positive effect on medical care expenditures.

The role of the health expenditures on growth has generally encouraging feature (Mushkin, 1962). This positive effect of health spending in the literature is explained by "Health-led growth hypothesis". According to the health-led growth hypothesis, health expenditure has characteristics of productive capital. On the other hand, according to Bloom \& Canning (2000), health expenditure has positive effects on economic growth and prosperity. The reasons of positive impact are summarized as follows: Healthy individuals (employees) are more efficient; Healthy individuals affect positively human capital; an increase the average life expectancy is promoting an increase in physical investment.

The relationship between health spending and economic growth are described via four different approaches in the literature. The first one underlines the positive impact of health expenditure on economic growth (Hansen \& King, 1996 and Tang, 2011). These studies expressed that health expenditures unilaterally leads to economic growth. The second group of studies express that there are two-way causality between economic growth and health spending (Elmi \& Sadeghi, 2012; Mehrara \& Musai, 2011). The third group expresses that there is no 
causal relationship between economic growth and health spending (Gerdtham \& Jönsson, 1991). The last group of studies express that health expenditures are affect economic growth negatively.

A lot of study has been done between financial development and economic growth. In these studies, financial intermediaries support economic growth by contributing to the effective distribution and supervision of savings, transferring them to investments, reducing asymmetric information, directing funds to innovative projects, monitoring managers' performances and ensuring financial transactions (Gregorio and Guidotti, 1995; Arestis and Demetriades, 1997; Levine, 1997; Boyd and Prescott, 1986; Capasso, 2004; Hassan and Sanchez, 2011; Altay and Topcu, 2017).

\section{Variables, Model and Data}

The main objective of this study is to test the existence of the relationship between human capital health index (HCHI) and financial development index (FDI) over the period 1991-2014 on the 10 high income countries (Luxemburg, Switzerland, Denmark, Australia, Sweden, Hungary, Poland, Portugal, Spain, Israel).

Many studies have been carried out on creating an index from financial variables (Domestic credit provided by banking sector (\% of GDP), domestic credit to private sector (\% of GDP), Liquid liabilities (M3) (\% of GDP), bank liquid reserves to bank assets ratio, gross capital formation (\% of GDP),... etc.) in order to investigate the relationship between financial variables and economic variables on different country and country groups (Shahbaz et al. (2016); Topcu and Payne, (2017); Narayan and Narayan (2013); Masih et al.(2009); Saci and Holden (2008); Çoban and Topcu (2013); Menyah et al. (2014); Topcu and Çoban, (2017)). We will follow these studies to construct an index set of financial variables. The data of these variables are gathered from the World Bank Financial Structure Database (2016).

We will create four indexes of financial variables using PCA. Financial development index (FDI) consists of the combination of 11 variables expressed following the previous study. Financial development index (FDI) consist of eleven variables (deposit money banks' assets to GDP (\%), financial system deposits to GDP (\%), liquid liabilities to GDP (\%), outstanding domestic private debt securities to GDP (\%), outstanding domestic public debt securities to GDP (\%), outstanding international private debt securities to GDP (\%), outstanding international public debt securities to GDP (\%), private credit by deposit money banks to GDP (\%), stock market capitalization to GDP (\%), stock market total value traded to GDP (\%) and stock market turnover ratio (\%)) combination with PCA method. In addition that, FDI is divided into three sub-indices banking index (BI), bound marketing index (BMI) and stock marketing index (SMI). Banking index (BI) is composed of deposit money banks' assets to GDP (\%), financial system deposits to GDP (\%), liquid liabilities to GDP (\%) and outstanding domestic private debt securities to GDP (\%) variables. Bound marketing index (BMI) is composed of outstanding domestic public debt securities to GDP (\%), outstanding domestic private debt securities to GDP (\%), outstanding international private debt securities to GDP (\%) and outstanding international public debt securities to GDP (\%) variables. Lastly, stock marketing index (SMI) is composed of stock market capitalization to GDP (\%), stock market total value traded to GDP (\%) and stock market turnover ratio (\%) variables. 
In the internal growth models literature, human capital variables are shown as the main source of economic growth, and this is supported by many empirical studies (Romer, 2012; Barro, 1991; Lucas, 1988). In this context, The Human Development Index (HDI) is being developed by the United Nations Development Organization (UNDP). This index has been published regularly since 1990 . The human development index shows a peaceful environment, a healthy lifestyle and a high level of education that individuals have. In addition that, The human capital index (HCI) has been published by World Bank since 2013. This index is based on four basic variables (education, enabling environment, health-wellness and workforce-employment). So, health in these indices has significant value. We created a new health index based on the HCI published by the World Bank and the HDI published by the United Nations. The share of the health index is $1 / 3$ in $\mathrm{HDI}$ and $1 / 4 \mathrm{in} \mathrm{HCl}$. At the same time, these sub-health indices is only based on the life expectancy of individuals ( $\mathrm{HDI}_{\text {health }}$ and $\mathrm{HCI}_{\text {health }}$ ). But the newly created health index considers more than one health variable.

Human capital health index (HCHI) consists of eight variables (life expectancy at birth, health expenditure, total (\% of GDP), fertility rate, total (births per woman), tuberculosis death rate (per 100,000 people), hospital beds (per 1000 people), mortality rate, infant (per 1,000 live births), mortality rate, under-5 (per 1000 people), and death rate (per 1000 people)) combination with PCA method. The data of these variables are gathered from the World Bank Health Nutrition and Population Statistics.

In this paper, we investigate the dynamic linkages between health variables and financial development for the selected high income countries during the period 1991-2014 using Dumitrescu and Hurlin panel causality test. Health capital health development index (HCHDI) is described as a function of income $(y)$ and financial development $(F D I)$.

$$
H C D H I_{i t}=\alpha_{i} H C H D I_{i t-1}+\beta_{i 1} y_{i t}+\beta_{i 2} F D I_{i t}+v_{i}+\varepsilon_{i t}
$$

where $i$ indicates the country $(\mathrm{i}=1, \ldots, 27)$ and $\mathrm{t}$ indicates the time period $(\mathrm{t}=1991, \ldots 2014)$. We gathered annual data on health indicators, real GDP per capita and financial development indicators for the period 1991-2014. The data of real GDP per capita is measured as constant 2005 US dollars. Since foreign direct investment is regarded as an emerging financial market determinant, it is added into the model. It is measured as net inflows as a share of GDP and denoted by FDI. All the data are sourced from the World Bank World Development Indicators (WDI) database.

\section{Methodology: PCA and Panel Causality}

This part of our study consists of two phases. The first step is formed into an index our variables using Principal component analysis (PCA). We collect health variables into a single index (HCHI). We will create four index (financial development index, stock marketing index, bound marketing index and bank index) using financial variables. In the second stage, we will apply our data set panel co-integration and causality test. As a finally step, the findings we obtained will give in the section of empirical results.

The principal component analysis is a multivariate statistical method which allows the dimension covariance structure of a set of variables to be reduced and interpreted by means of linear combinations of these variables. $\mathrm{P}$ variables indicating the structure of interdependence in 
the method are converted into $\mathrm{k}(k \leq p)$ new variables carrying the features linear, orthogonal and independent of each other.

Linear combination or basic component of $Z_{1}, Z_{2}, \ldots, Z_{p}$ vectors $(p)$ which are the standardized form of vectors $\mathrm{X}_{1}, \mathrm{X}_{2}, \ldots, \mathrm{X}_{\mathrm{p}}$;

$$
\begin{gathered}
\mathrm{Y}_{1}=\mathrm{A}_{11} \mathrm{Z}_{1}+\mathrm{A}_{21} \mathrm{Z}_{2}+\ldots \ldots \ldots+\mathrm{A}_{1 \mathrm{p}} \mathrm{Z}_{\mathrm{p}} \\
\mathrm{Y}_{2}=\mathrm{A}_{21} \mathrm{Z}_{1}+\mathrm{A}_{22} \mathrm{Z}_{2}+\ldots \ldots \ldots+\mathrm{A}_{2 \mathrm{p}} \mathrm{Z}_{\mathrm{p}} \\
\mathrm{Y}_{\mathrm{p}}=\mathrm{A}_{\mathrm{p} 1} \mathrm{Z}_{1}+\mathrm{A}_{\mathrm{p} 2} \mathrm{Z}_{2}+\ldots \ldots \ldots+\mathrm{A}_{\mathrm{pp}} \mathrm{Z}_{\mathrm{p}}
\end{gathered}
$$

In this set of equations, $\mathrm{Z}_{1}, \mathrm{Z}_{2}, \ldots, \mathrm{Z}_{\mathrm{p}}$ is the row vector of the standardized data matrix; $\mathrm{Y}_{1}, \mathrm{Y}_{2}, \mathrm{Y}_{3}, \ldots, \mathrm{Y}_{\mathrm{p}}$ basic components and $\mathrm{A}_{\mathrm{pp}}$ are the basic component loads that indicate which variables and which core components each will be associated with. The basic component loads $\left(\mathrm{A}_{\mathrm{pp}}\right)$ are the weights of the base components showing the variance contribution to the variables. Variances and covariances of the principal components;

$$
\begin{array}{lr}
\operatorname{Var}\left(\mathrm{Y}_{\mathrm{i}}\right)=\operatorname{Var}\left(\left(\mathrm{A}_{\mathrm{i}}\right) \mathrm{Z}\right)=(\mathrm{Ai})^{\mathrm{t}} \cdot \mathrm{Sa}_{\mathrm{i}}=\left(\mathrm{A}_{\mathrm{i}}\right) \cdot \mathrm{Ra}_{\mathrm{i}} & \mathrm{i}=1,2,3, \ldots, \mathrm{p} \\
\operatorname{Cov}(\mathrm{Yi}, \mathrm{Yk})=(\mathrm{Ai})^{\mathrm{t}} \cdot \mathrm{Sa}_{\mathrm{i}}=\left(\mathrm{A}_{\mathrm{i}}\right) \cdot \mathrm{Ra}_{\mathrm{k}} & \mathrm{k}=1,2,3, \ldots, \mathrm{p}
\end{array}
$$

The $\mathrm{Y}_{1}$ principal component is selected to have $\left(\mathrm{Y}_{1}=\mathrm{A}_{11} \mathrm{Z}_{1}+\mathrm{A}_{12} \mathrm{Z}_{2}+\ldots \ldots+\mathrm{A}_{1 \mathrm{p}} \mathrm{Z}_{\mathrm{p}}\right)$ the maximum contribution to the total variance. $A_{1}$ vector is determined to be $\operatorname{Max} \operatorname{Var}\left(\mathrm{Y}_{1}\right)$ and $\left(\left(a_{1}\right)^{t} \cdot a_{1}=1\right)$ from the equation $\operatorname{Max} \operatorname{Var}\left(Y_{1}\right)=\left(a_{1}\right)^{t} R a_{1}$. Similarly, $a_{2}$ vector provides the conditions $\max \operatorname{Var}\left(\mathrm{Y}_{2}\right)$ and $\left(\left(\mathrm{a}_{2}\right)^{\mathrm{t}} \cdot \mathrm{a}_{2}=1\right)$ to determine the basic component $\mathrm{Y}_{2}$. Hence, $\mathrm{Y}_{\mathrm{i}}$ is the linear combination of $\left(a_{i}\right)^{t} Z$ satisfied the conditions of $\max \operatorname{Var}\left(Y_{i}\right),\left(\left(a_{i}\right)^{t} \cdot a_{i}=1\right)$ and $\operatorname{Cov}\left(Y_{i}, Y_{k}\right)=0$. In short, the method we will follow in basic component analysis; The data matrix of $p$ variables is standardized, the correlation matrix is calculated, eigenvalues and eigenvectors of the correlation matrix are calculated, the ratio of disclosure of the total variance of the principal components is obtained from the core values and the basic component values are found by multiplying the transpose of each eigenvector by the standardized data matrix. ${ }^{4}$

\subsection{Testing of Cross Section Dependency}

The cross-section dependency between the series affects the results of the analysis. Therefore, this situation needs to be taken into account in the analyzes (Pesaran, 2007). For this reason it is necessary to test the horizontal section dependency in the series before starting the analyzes. Cross section dependency is not considered when unit root and cointegration tests are selected; the results of the analysis made may be biased and inconsistent.

Cross section dependency between the series can be examined by Breusch-Pagan (1980) LM test or Pesaran (2007) CD test. Berusch-Pagan (1980) LM test is used when the time dimension is larger than the horizontal section size (T> N). However, the Pesaran (2007) CD test can be used both when the time dimension is greater than the horizontal section size and

\footnotetext{
${ }^{4}$ The weights obtained from the principal component analysis with respect to each indicator and country are not reported as it is very tough to report all indexes for each country within the sample. They are, however, available upon request.
} 
when the horizontal section size is larger than the time dimension $(\mathrm{T}>\mathrm{N}, \mathrm{N}>\mathrm{T})$. These tests are biased when the group mean is zero but the individual mean is different from zero. Pesaran, Ullah and Yamagata (2008) corrected this bias by adding variance and mean to the test statistic. For this reason the name of this test is expressed as bias corrected LM test $\left(\mathrm{LM}_{\mathrm{adj}}\right)$.

In this study, the presence of cross-sectional dependence in the variables is analyzed using CD test and the results are presented in Table 1.

Table 1: Cross Section Dependence Test Results CD-test (Pesaran, 2007)

\begin{tabular}{cccccc}
\hline Variables & loghchdi & logfdi & logbi & logsmi & logbmi \\
\hline 30,42 & 25,34 & 21,19 & 15,08 & 16,93 \\
& $(0,000)^{*}$ & $(0,000)^{*}$ & $(0,000)^{*}$ & $(0,000)^{*}$ & $(0,000)^{*}$ \\
\hline
\end{tabular}

Note: The parentheses indicate the probe values. *,**, *** indicate significance at $1 \%, 5 \%$ and $10 \%$, respectively.

With the results of the CD test presented in table 1 it is decided that there is cross section dependency in each series.

\subsection{Panel Unit Root Tests}

The first problem encountered in the panel unit root test is whether the cross sections forming the panel are independent of each other. At this point, panel unit root tests are divided into first and second generation tests. In our study, we will use the second generation unit root tests taking into account cross section addiction. The main known second-generation unit root tests are; MADF (Taylor ve Sarno, 1998), SURADF (Breuer, Mcknown ve Wallace, 2002), CADF (Pesaran, 2007) ve PANKPSS (Carrion-i-Silvestre et al., 2005).

In this study, the second generation unit root tests were examined by the CADF test developed by Pesaran (2007). The CADF test can be used to perform unit root tests in each cross section (for each country). Thus, the stationary of the series can be calculated separately for the panel and for each cross section. The CADF test which assumes spatial autocorrelation, assuming that each country is affected differently from time effects, is used in the $\mathrm{T}>\mathrm{N}$ and $\mathrm{N}>$ $\mathrm{T}$ cases. Stationarity is tested for each country by comparing these test statistic values with Pesaran (2007)'s CADF critical table values. If the CADF critical table value is greater than the CADF statistical value, the null hypothesis is rejected. The CADF test statistic estimates as follows:

$$
\begin{gathered}
Y_{i, t}=\left(1-\emptyset_{i}\right) \mu_{i}+\emptyset_{i} y_{i, t-1}+u_{i, t} \quad(i=1,2 \ldots N \text { and } t=1,2 \ldots T) \\
u_{i, t}=\gamma_{i} f_{t}+\varepsilon_{i, t}
\end{gathered}
$$

In this equation, $\boldsymbol{f}_{\boldsymbol{t}}$ is the unobservable common effect of each country, $\boldsymbol{\varepsilon}_{\boldsymbol{i}, \boldsymbol{t}}$ indicates an individual-specific error. Equations (5), (6) and unit root hypotheses can be written as;

$$
\begin{aligned}
\Delta y_{i t} & =\alpha_{i}+\beta_{i} y_{i, t-1}+\gamma_{i} f_{t}+\varepsilon_{i, t} \quad(i=1,2 \ldots N \text { and } t=1,2 \ldots T) \\
\mathrm{H}_{0}: \beta_{i} & =0 \text { (for all } i \text { values) series are not stationary. } \\
\mathrm{H}_{1}: \beta_{i} & <0 \text { series are stationary. }
\end{aligned}
$$

In addition, cross-sectionally augmented IPS (CIPS), which is the unit root test statistic for the panel, can be obtained by taking the average of the unit root test statistics of each horizontal section (countries) (Pesaran, 2007). The CIPS statistic can be expressed as: 


$$
\text { CIPS }=N^{-1} \sum_{i=1}^{N} C A D F_{i}
$$

Critical values calculated by Pesaran (2007) and the unit root statistics (CIPS) for each panel making country are given in Table 2 .

When the results in Table 2 are examined, it is seen that only stock market index (smi) variable is $\mathrm{I}(0)$ while others are $\mathrm{I}(1)$.

Table 2: CIPS Unit Root Test Results

\begin{tabular}{|c|c|c|c|c|}
\hline \multirow{2}{*}{ Variables } & \multicolumn{2}{|c|}{ Level } & \multicolumn{2}{|c|}{ First Difference } \\
\hline & Trend + Constant & Fixed & Trend + Constant & Fixed \\
\hline \multirow{2}{*}{ loghchdi } & 1.556 & -2.246 & -0.952 & $-1.660 * *$ \\
\hline & $(0.940)$ & $(0.988)$ & $(0.171)$ & $(0.048)$ \\
\hline \multirow{2}{*}{ logbmi } & 0.980 & 1.785 & $-3.683^{*}$ & $-4.324 *$ \\
\hline & $(0.000)$ & $(0.963)$ & $(0.000)$ & $(0.000)$ \\
\hline \multirow{2}{*}{ logbi } & -0.568 & 0.733 & -1.096 & $-2.317 * *$ \\
\hline & $(0.285)$ & $(0.768)$ & $(0.137)$ & $(0.010)$ \\
\hline \multirow{2}{*}{$\operatorname{logfdi}$} & -0.852 & -0.403 & $-3.281 *$ & $-4.292 *$ \\
\hline & $(0.197)$ & $(0.343)$ & $(0.001)$ & $(0.000)$ \\
\hline \multirow{2}{*}{ logsmi } & $-6.613 *$ & $-4.873^{*}$ & & \\
\hline & $(0.000)$ & $(0.000)$ & & \\
\hline \multirow{2}{*}{ logincome } & -1.026 & -1.049 & $-2.531 *$ & $-3.029 *$ \\
\hline & $(0.152)$ & $(0.2210)$ & $(0.006)$ & $(0.001)$ \\
\hline
\end{tabular}

Note: $*, * *, * * *$ indicate significance at $1 \%, 5 \%$ and $10 \%$, respectively. Critical values for the panel were taken from Pesaran (2007) study. The number of delays is determined by the Schwarz-Bayesian Information Criteria (SBC). The parentheses indicate the probe values. A lagged value of the variables is taken.

\subsection{Dumitrescu And Hurlin Panel Causality Test}

In this study, the causality relation between the series was investigated by the method developed by Dumitrescu and Hurlin (2012). The main advantage of the test of Dumitrescu and Hurlin (2012) over the other tests is that the test considers the cross-section dependency among the panel units. Apart from this, the other superior aspect of the test is that it is insensitive to the size difference between time dimension and section size. That is, when the time dimension is larger or smaller than the section size, the test can produce effective results.

Dumitrescu and Hurlin (2012) investigated the causality relationship between Y and X with the help of the linear model given below.

$$
\begin{gathered}
y_{i, t}=\alpha_{i}+\sum_{k=1}^{K} \gamma_{i}^{(k)} y_{i, t-k}+\sum_{k=1}^{K} \beta_{i}^{(k)} X_{i, t-k}+\varepsilon_{i, t} \\
\beta_{i}=\left(\beta_{i}^{(1)}, \ldots, \beta_{i}^{(K)}\right)
\end{gathered}
$$

$\mathrm{K}$ represents the same length of delay for all cross sections. The basic and alternative hypotheses established for the above equation are as follows.

$$
\begin{gathered}
H_{0}: \beta_{i}=0 \\
H_{1}: \beta_{i}=0, \forall_{i}=1,2, \ldots, N \\
\beta_{i} \neq 0, \forall_{i}=N_{1}+1, N_{2}+1, \ldots, N
\end{gathered}
$$

Dumitrescu and Hurlin (2012) calculated individual Wald statistics $\left(\mathrm{W}_{\mathrm{i}, \mathrm{T}}\right)$ for crosssectional units in order to test basic and alternative hypotheses. Furthermore, they obtained the 
Wald statistic $\left(W_{N, T}^{H N C}\right)$ of the panel by taking the average of these statistics. In other words; $W_{N, T}^{H N C}=1 / \mathrm{N} . \sum_{i=1}^{N} W_{i, T}$. Dumitrescu and Hurlin (2012) recommend using $Z_{N, T}^{H N C}$ statistic with asymptotic distribution when the time dimension is larger than the cross-sectional dimension. In the opposite case, the use of $Z_{N}^{H N C}$ statistic is recommended if the section size is larger than the time dimension. $Z_{N, T}^{H N C}$ and $Z_{N}^{H N C}$ test statistics are calculated as follows;

$$
\begin{aligned}
Z_{N, T}^{H N C} & =\sqrt{\frac{N}{2 k}}\left(W_{N, T}^{H N C}-K\right) \stackrel{N \rightarrow \infty}{\longrightarrow} N(0,1) \\
Z_{N}^{H N C} & =\frac{N^{-1 / 2}\left[W_{N, T}^{H N C}-N^{-1} \cdot \sum_{i=1}^{N} E\left(W_{i, T}\right)\right.}{\sqrt{N^{-1} \sum_{i=1}^{N} \operatorname{Var}\left(W_{i, T}\right)}} \stackrel{N \rightarrow \infty}{\longrightarrow} N(0,1)
\end{aligned}
$$

In this study, Dumitrescu and Hurlin (2012) panel causality test was applied to the stationary series. The results are presented in Table 3. Since the time dimension in the study is larger than the horizontal section size, the directions of causality relations between the series have been decided on the basis of the results of $Z_{N, T}^{H N C}$ test statistic suggested by Dumitrescu and Hurlin (2012).

When we examine the empirical results in Table 3, income variable affects the banking index and bond market index after one period lag. When we look at the results of 2-term lagged analysis, income variable affects the banking index. The bond market index affects the income variable. The health index also affects the bond market index after with two lags. Finally, when we examine the results of three lagged analyzes, we see that the effects of the health index become more apparent. The health index affects all financial sub-indices (bi, bmi and smi). On the other hand, the bond market index affects only the health index. The income variable affects the bond market index and the banking index. Therefore, the income variable affects financial sub-indices at all lag levels. But the financial development index do not affect any variables and is not affected by them. The income variable do not affect the change in health index in addition to the vice versa. The smi index is not found to have a significant relationship with other variables. The health variable influences the smi with three lags. Thus, it could be inferred that there is a strong causal link between the bi, bmi variables and income.

When we examine the consequences of causation according to the lag length, we see that the income variable affects the bi and bmi variables. When the results for lag 3 are considered, the health variable (hchdi) affects bi, bmi and smi variables and is also affected by them. Finally, it is seen that the income variable affects the variables bi and bmi at all lag lengths.

\section{Conclusion}

The relationship between the health variable which is one of the determinants of human capital, and financial development has been analyzed over the period 1991-2014 in the selected high income countries. Health and financial development variables are used to construct a single variable by the PCA method. Then causality analysis is performed on the indexes. According to the results of our study, health variables are affecting financial sub-variables in the long run. On the contrary, income does not directly affect the health variable. But the income variable indirectly influences the health variable through financial sub-variables. In addition, financial development index which are aggregate of the financial variables do not affect any variables and 
are not influenced by any variable. Therefore, the influence mechanism has been found to have come to fruition through financial sub-variables (banking index and bound marketing index). As a result, income and health variables indirectly affect each other through financial sub-indices. This mechanism is beginning to affect the financial developments of income in the short term. In the long term, we find that health variable affects sub-financial variables in the selected high income countries. 
Table 3: Dumitrescu and Hurlin (2012) Panel Causality Test Results

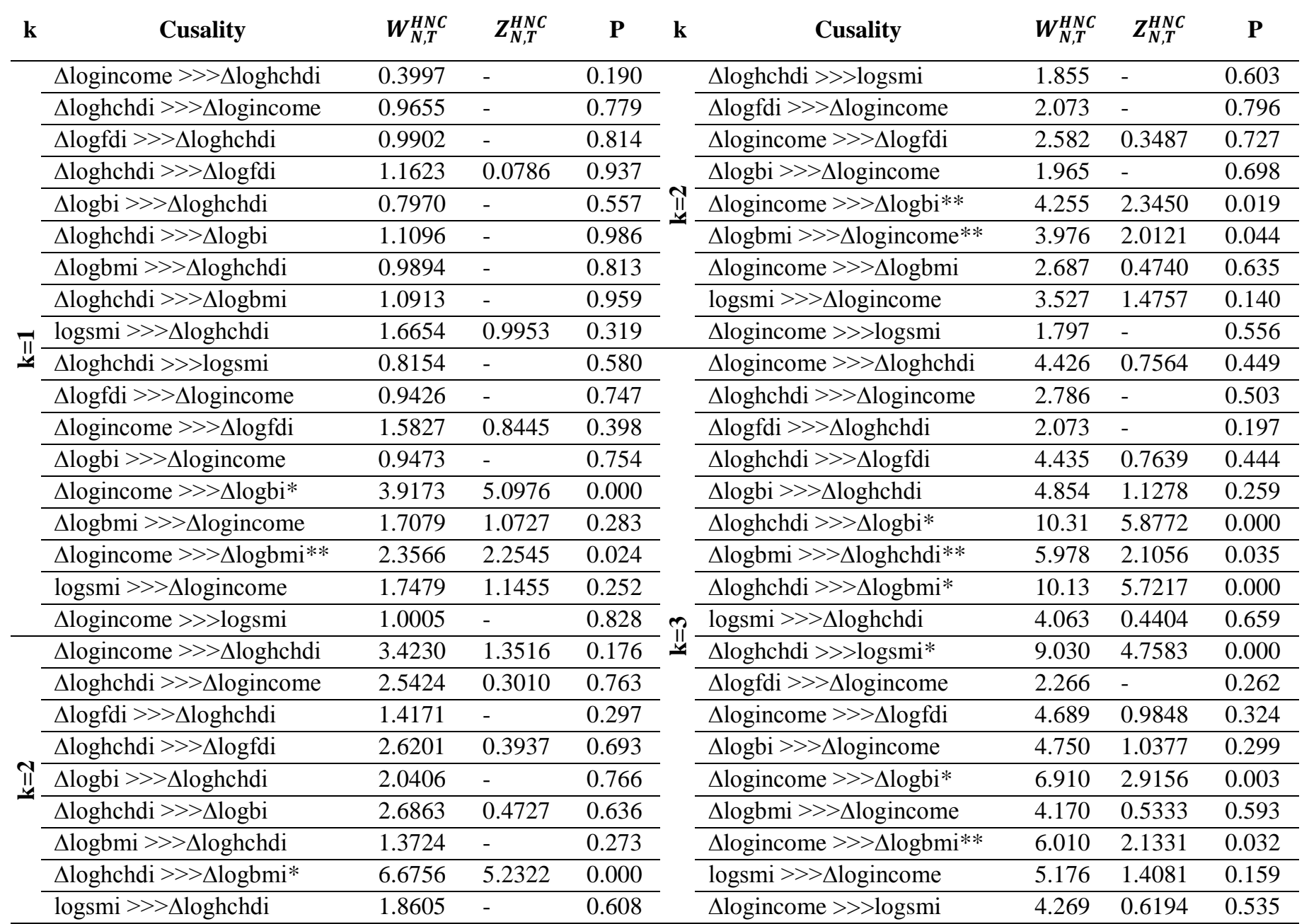

Note: Values in parentheses indicate p-probability values, *,**,*** indicate significance at $1 \%, 5 \%$ and $10 \%$, respectively. $\mathbf{k}$ represents the number of delays. $\Delta$ means that the first differences of the variables are received. 
A.Kuloğlu \& E. Ecevit, “The Relationshıp Between Health Development Index and Financial Development Index: Evidence From High Income Countries"

\section{References}

Altay, B., \& Topcu, M. (2017). Re-Examining the Impact of Financial System on Economic Growth: New Evidence From Heterogeneous Regional Panels. In Handbook of Research on Global Enterprise Operations and Opportunities (pp. 1-16). IGI Global.

Arrow, K. (1962). Economic Welfare and the Allocation of Resources for Invention. In The rate and direction of inventive activity: Economic and social factors (pp. 609-626). Princeton University Press.

Barro, R. J. (1990). Government Spending in a Simple Model of Endogeneous Growth. Journal of political economy 98(5, Part 2): S103-S125.

Barro, R. J. (1991). Economic Growth in a Cross Section of Countries. The quarterly journal of Economics 106(2): 407-443.

Breuer, J. B., McNown, R., \& Wallace, M. (2002). Series-Specific Unit Root Tests with Panel Data. Oxford Bulletin of Economics and statistics 64(5): 527-546.

Lluís Carrion-i-Silvestre, J., Barrio-Castro, D., \& López-Bazo, E. (2005). Breaking the Panels: an Application to the GDP per capita. The Econometrics Journal 8(2): 159-175.

Choi, I. (2001). Unit Root Tests for Panel Data. Journal of international money and Finance 20(2): 249272.

Çoban, S., \& Topcu, M. (2013). The Nexus Between Financial Development and Energy Consumption in the EU: A Dynamic Panel Data Analysis. Energy Economics 39: 81-88.

Dumitrescu, E. I., \& Hurlin, C. (2012). Testing for Granger Non-causality in Heterogeneous Panels. Economic Modelling 29(4): 1450-1460.

Elmi, Z. M., \& Sadeghi, S. (2012). Health Care Expenditures and Economic Growth in Developing Countries: Panel Co-integration and Causality. Middle-East Journal of Scientific Research 12(1): 88-91.

Gerdtham, U. G., \& Jönsson, B. (1991). Price And Quantity in İnternational Comparisons of Health Care Expenditure. Applied Economics 23(9): 1519-1528.

Grossman, M. (1972). On The Concept Of Health Capital And The Demand For Health. Journal of Political economy 80(2): 223-255.

Grossman, M. (1999). The human capital model of the demand for health (No. w7078). National Bureau of Economic Research.

Hansen, P., \& King, A. (1996). The Determinants Of Health Care Expenditure: A Cointegration Approach. Journal of health economics 15(1): 127-137.

Im, K. S., Pesaran, M. H., \& Shin, Y. (2003). Testing For Unit Roots in Heterogeneous Panels. Journal of econometrics 115(1): 53-74.

Kaldor, N., \& Mirrlees, J. A. (1962). A New Model Of Economic Growth. The Review of Economic Studies 29(3): 174-192.

Levine, R. (1997). Financial Development And Economic Growth: Views And Agenda. Journal of economic literature 35(2): 688-726.

Lucas, R. E. (1988). On The Mechanics Of Economic Development. Journal of monetary economics 22(1): 3-42.

Maddala, G. S., \& Wu, S. (1999). A Comparative Study Of Unit Root Tests With Panel Data And A New Simple Test. Oxford Bulletin of Economics and statistics 61(S1): 631-652.

Masih, M., Al-Elg, A., \& Madani, H. (2009). Causality Between Financial Development And Economic Growth: An Application Of Vector Error Correction And Variance Decomposition Methods To Saudi Arabia. Applied Economics 41(13): 1691-1699.

Mehrara, M., \& Musai, M. (2011). Granger causality between Health and Economic Growth in oil exporting countries. Interdisciplinary Journal of Research in Business 1(8): 103-108.

Menyah, K., Nazlioglu, S., \& Wolde-Rufael, Y. (2014). Financial Development, Trade Openness And Economic Growth in African Countries: New Insights From A Panel Causality Approach. Economic Modelling 37: 386-394.

Mushkin, S. J. (1962). Health as an Investment. Journal of political economy, 70(5, Part 2):129-157. 
Ekonomi, Politika \& Finans Araştırmaları Dergisi, 2017, 2(2): 83-95.

Journal of Research in Economics, Politics \& Finance, 2017, 2(2): 83-95.

Narayan, P. K., \& Narayan, S. (2013). The Short-Run Relationship Between The Financial System And Economic Growth: New Evidence From Regional Panels. International Review of Financial Analysis 29: 70-78.

Newhouse, J. P. (1977). Medical-care expenditure: a cross-national survey. The Journal of Human Resources 12(1): 115-125.

Pedroni, P. (1999). Critical Values for Cointegration Tests in Heterogeneous Panels with Multiple Regressors. Oxford Bulletin of Economics and statistics 61(S1): 653-670.

Pesaran, M. H. (2007). A Simple Panel Unit Root Test in the Presence of Cross-section Dependence. Journal of Applied Econometrics 22(2): 265-312.

Rebelo, S. (1991). Long-Run Policy Analysis and Long-Run Growth. Journal of Political Economy 99(3): 500-521.

Romer, P. M. (1986). Increasing Returns and Long-Run Growth. Journal of political economy 94(5): 1002-1037.

Saci, K., \& Holden, K. (2008). Evidence on Growth and Financial Development Using Principal Components. Applied Financial Economics 18(19): 1549-1560.

Shahbaz, M., Shahzad, S. J., Ahmad, N., \& Alam, S. (2016). Financial Development and Environmental Quality: The Way Forward. Energy Policy 98: 353-364.

Soukiazis, E., \& Cravo., T. (2008). Human Capital and The Convergence Process Among Countries. Review of Development Economics 12(1): 124-142.

Tang, C. F. (2011). Multivariate Granger Causality and the Dynamic Relationship Between Health Care Spanding, Income and Relative Price of Health Care in Malaysia. Hitotsubashi Journal of Economics, 52(2): 199-214.

Taylor, M. P., \& Sarno., L. (1998). The Behavior of Real Exchange Rates During The Post-Bretton Woods Period. Journal of International Economics 46(2): 281-312.

Topcu, M., \& Çoban, S. (2017). Financial Development and Firm Growth in Turkish Manufacturing Industry: Evidence From Heterogeneous Panel Based Non-Causality Test. Economic ResearchEkonomska Istraživanja 30(1), 1758-1769.

Topcu, M., \& Payne, J. (2017). The Financial Development-Energy Consumption Nexus Revisited. Energy Sources, Part B: Economics, Planning, and Policy 12(9): 1-9.

Uzawa, H. (1965). Optimum Technical Change in An Aggregative Model of Economic Growth. International Economic Review 6:18-31. 